\title{
CHANGES IN CLIMATE AND VEGETATION IN AUSTRALIA DURING THE TERTIARY
}

\author{
DAVID C. CHRISTOPHEL and DAVID R. GREENWOOD \\ Botany Department, University of Adelaide, GPO Box 498, Adelaide, S.A. 5001 (Australia)
}

(Received February 25, 1988; revised and accepted October 25, 1988)

\begin{abstract}
Christophel, D.C. and Greenwood, D.R., 1989. Changes in climate and vegetation in Australia during the Tertiary. Rev. Palaeobot. Palynol., 58: 95-109.

The megafossil floras of southern Australia indicate the presence of taxonomically diverse rainforests where Nothofagus (Fagaceae) was restricted in occurrence. Further, these megafossil floras contain a common set of taxa whose modern relatives are either restricted to the tropical and subtropical rainforests of Northeast Queensland, or are found in equivalent habitats in neighbouring landmasses. Examination of modern stream transported leaf litter in Australian rainforest suggests that "foliar physiognomic signatures" detected in modern leaf litter can be used to interpret Early Tertiary leaf assemblages. The foliar physiognomic signatures of the Eocene floras indicate Microthermal to Mesothermal (?and Megathermal) rainforests. The palaeolatitude and altitude of the megafossil floras suggests vegetational-climatic belts in southern Australia in the Eocene, with Mesothermal rainforests replaced by Microthermal rainforests in the region of modern Victoria and Tasmania.

Palynological and megafossil evidence point to a deterioration in climate in southern Australia during the Oligo-Miocene. The foliar physiognomy and floristic composition of the Latrobe Valley coal floras suggests a shift to more seasonal climates rather than a dramatic drop in the annual average temperature, with sclerophyllous vegetation supplanting the Eocene rainforests. Pliocene floras indicate the appearance of modern taxa and vegetation, although pollen studies in Northeast Queensland demonstrate large fluctuations in the boundaries and spatial extent of the modern vegetation types during the Plio-Pleistocene. The modern rainforests of Australia are therefore interpreted as being essentially relictual, although Late Tertiary extinctions have produced patterns of endemism which mask their common ancestry.
\end{abstract}

\section{Introduction}

Changes in plant cover and climate during the Tertiary can only be considered in the light of the documented megafossil floras of the region. Christophel reviewed the Tertiary evolution of key components of the Australian flora (Christophel, 1989). In this paper, we intend to consider the Australian Tertiary from the point of view of the plant communities. At the outset we will briefly review the microfloral evidence which has provided much of the basis for earlier interpretations of Australian Tertiary vegetation, and summar- ise the better known Australian Tertiary megafossil localities which provide the data base for our studies. The second half of the paper will deal with community and climatic reconstructions of Australian Tertiary megafossil floras based on foliar physiognomic analysis.

Foliar physiognomic analysis has recently experienced a resurgence with several papers on North American Cretaceous and Tertiary floras (e.g. Wolfe, 1987; Wolfe and Upchurch, 1987) providing detailed analyses of past climates. However, here we apply a methodology distinct from that used by Wolfe $(1980,1987)$. A 
recent study of leaf-beds formed in modern Australian rainforests found that the "foliar physiognomic signatures" of modern Australian rainforest types matched those of Tertiary floras (Greenwood, 1987a; Christophel and Greenwood, 1987, 1988). Christophel and Greenwood used this evidence to interpret several Eocene floras and comment on the vegetation and climatic regimes represented by them. The work reported here extends that analysis to further deposits, and more of the Tertiary.

\section{Microfossil evidence}

The microfossil record of the Australian Tertiary has been the focus of much investigation over the last two decades. Kemp (1978, 1981) and Martin (1981) based their interpretations of Australian Tertiary vegetation and climate almost exclusively on palynological data. Their papers contain much of the background data used for Barlow's discussion of the evolution of the Australian flora in the introduction to "The Flora of Australia" (Barlow, 1981), and those four works can be considered together.

These palynological interpretations can be placed in some context by considering the modern vegetation of Australia (Fig.1). While seven major vegetation types are illustrated, three major climatic/vegetation regions may be considered. First is the arid to semi-arid region of shrublands (Acacia and Casuarina), shrub-steppe (Chenopodiaceae), and grasslands (graminoids), indicated by differing degrees of stippling on Fig.1. The characteristic Australian woodlands and forests dominated by Eucalyptus s.l. occupy an outer, wetter arc of the continent (indicated by diagonal bars), with a few areas of drier Eucalyptus-dominated shrublands ("mallee") in the southern half of the continent. Numerous patches of tropical to cool temperate rainforest occur in locally favourable sites along the eastern coastal margin and the western side of Tasmania

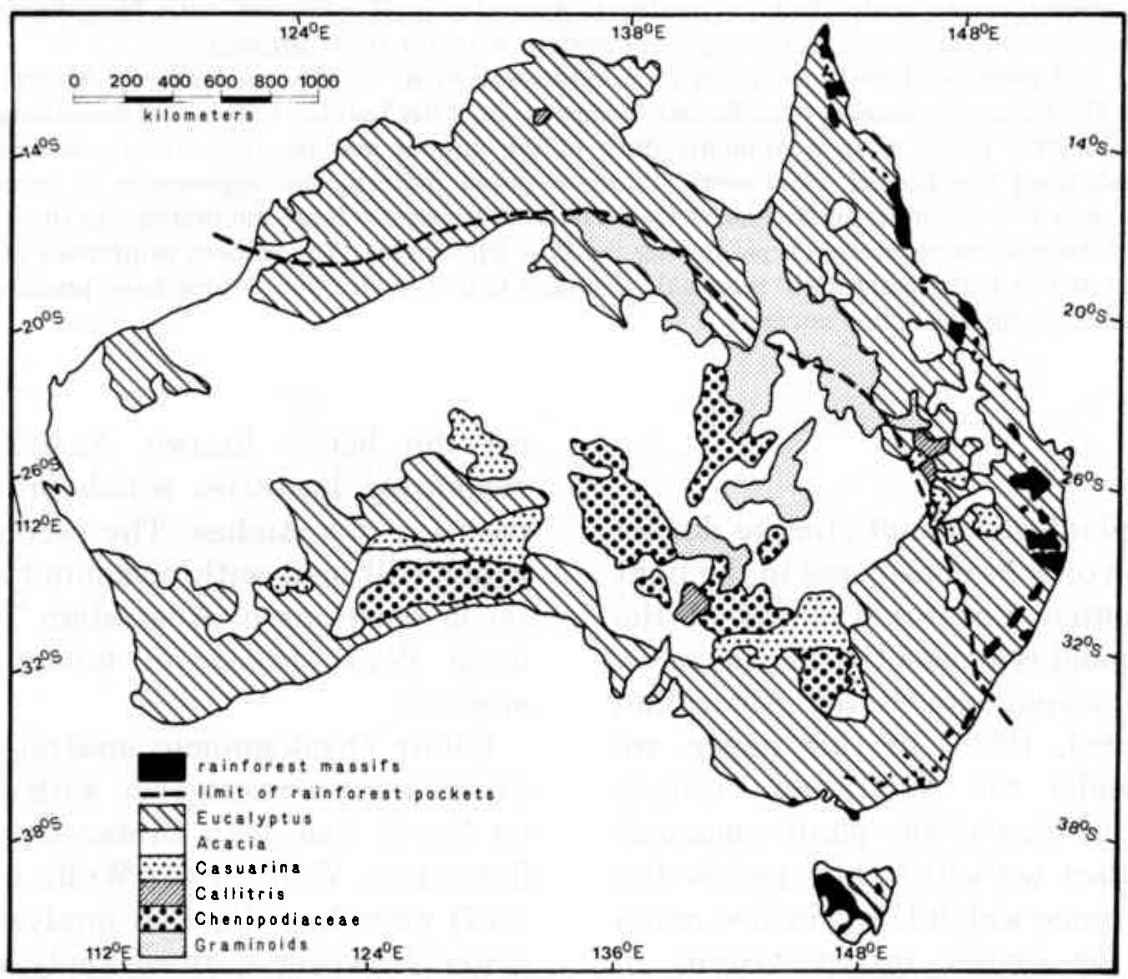

Fig.1. Simplified vegetation map of Australia. 
(indicated by solid black in Fig.1). The cool temperate rainforests are typically species poor and dominated by Nothofagus (Fagaceae), whereas the subtropical and tropical rainforests are typically species rich with no canopy dominants.

Australia in the Early Tertiary is considered to have lain at high southern latitudes and to have been linked via Tasmania to an ice-free Antarctica for much of the Eocene (Kemp, 1978). Many palynologists agree that in the Early Tertiary southern Australia was covered with rainforests, ranging from temperate to subtropical in character and containing characteristic southern taxa such as Araucariaceae, Podocarpaceae, Nothofagus (Fagaceae), and Proteaceae. Floras from the interior suggest a similar vegetation there (Truswell and Marchant, 1986). Some authors have considered this vegetation a "pan-Australian forest" in which Nothofagus was probably dominant, based on the ubiquitous, and often dominant occurrence of pollen of the $N$. brassii type in sediments of Early Tertiary age (e.g. Barlow, 1981). However, Foster (1983) described an Eocene flora from Queensland which is distinct from the southern Australian Eocene palynofloras. The reduced frequency of Nothofagus recorded by Foster (1983), and an increased frequency of other taxa, including palm pollen, can be interpreted as a rainforest of subtropical to tropical character, in contrast to the temperate to subtropical character of the southern palynofloras.

A change in vegetation is suggested for the Oligo-Miocene as important Eocene taxa, such as pollen of the Nothofagus brassii type, disappear from southern Australian sequences in this interval and are replaced by other taxa (Kemp, 1978; Luly et al., 1982; Truswell and Harris, 1982; Truswell et al., 1984). This change is thought to be linked to a climatic deterioration accompanying the final separation of Australia and Antarctica and the initiation of the circum-polar current (Kemp, 1978; Truswell and Harris, 1982).

Within the Latrobe Valley coal sequences there is a transition from predominantly rain- forest taxa in the Lower Miocene Morwell coal seam to predominantly sclerophytic taxa in the Middle Miocene Yallourn coal seam (Luly et al., 1982; Christophel, 1988). The Oligo-Miocene also marks the earliest reliable records of several Australian floristic elements characteristic of the arid and semi-arid regions, including Acacia, Chenopodiaceae, and graminoids (Martin, 1981; Truswell and Harris, 1982). Pollen evidence also supports the emergence of Eucalyptus s.l. as an important component of vegetation during this period as well.

The Pliocene in Australia is only known from a few studies (e.g. Kershaw and Sluiter, 1982). However, the Pleistocene has provided more data, and although essentially beyond the scope of this discussion, provides some important observations. Most of the present day vegetation types in Australia have been documented for the Pleistocene (Kershaw, 1981; Sluiter and Kershaw, 1982), and studies by Kershaw in northeastern Australia have suggested that the rainforests there now have varied in floristic character and alternated over part of their area with more open forests in cycles over the last several hundred thousand years (Kershaw, 1976, 1981).

For all of the above data, the basic assumption that Early Tertiary pollen grains identified to extant genera actually come from plants with other organs matching those extant plants must be remembered and occasionally questioned. A similar caution must be exercised when extrapolating the environmental requirements of fossil taxa from the nearest modern relative.

\section{Megafossil evidence}

The oldest, most numerous, and best documented of the Australian Tertiary megafossil localities under recent study are Eocene, as illustrated in Fig.2. Of these deposits, the Anglesea locality is best known. Much of the current information on this locality was summarised by Christophel et al. (1987). In their study, six clay lenses from Anglesea were 


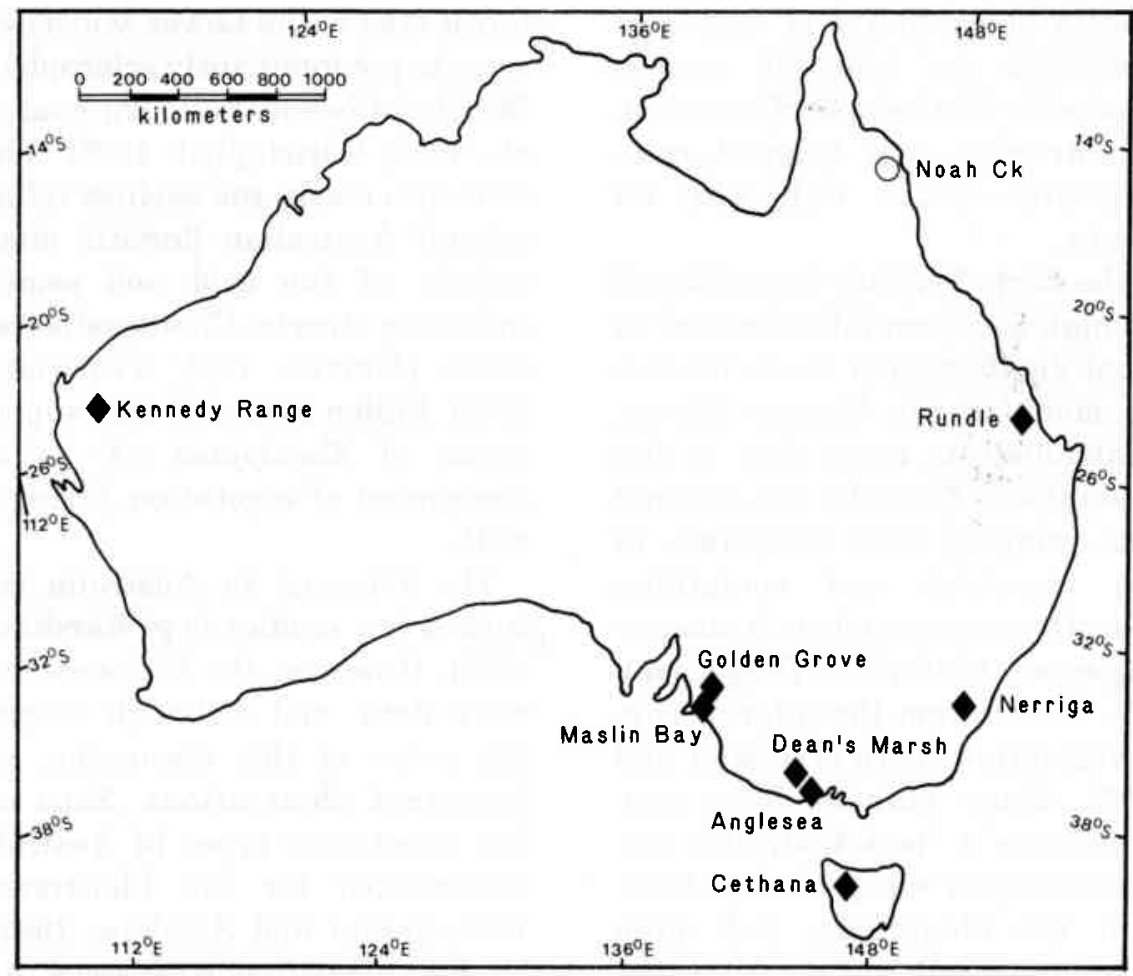

Fig.2. Australian Eocene megafossil floras.

examined for their megafossil and microfossil taxonomic composition. Their results suggested that the local vegetation contributing leaves to each of the lenses was of a different character, with some lenses dominated by a particular set of taxa. Eight of the taxa present in each of these lenses have modern nearest relatives restricted to the tropical rainforests of Northeast Queensland, suggesting that the Anglesea flora represents rainforest with a tropical character. Included amongst the eight taxa are: Gymnostoma (Casuarinaceae), Podocarpus (Podocarpaceae), a cycad - Bowenia (Zamiaceae), and Musgraveinanthus Christophel (Proteaeceae) (Christophel, 1984; Greenwood, 1987b; Christophel and Greenwood, 1988).

All of these taxa can only be found in close proximity in a small region of Northeast Queensland: Noah Creek (Figs.2, 3), in an area of tropical rainforest rich in primitive angiosperms and endemic taxa. Figure 3 also shows that the immediate region of Noah Creek represents a complex interaction of rainforest types produced by edaphic and topographic influences. This complexity can be used to explain the intra-lens differences at Anglesea, as it is reasonable to assume that a deposit formed in a similar situation may contain discrete input events from a variety of the local forest types.

Two Eocene Megafossil floras from Tasmania, Regatta Point and Hasties, also indicate the presence of diverse "subtropical" rainforests in the lowlands of that area, including Araucariaceae, Gymnostoma (Casuarinaceae), and the mangrove palm, Nypa (Hill and Gibson, 1986; Hill and Bigwood, 1987). The taxonomic composition of other southern Australian Eocene megafossil floras (Fig.2) at Nerriga, New South Wales (Hill, 1982, 1986), and Maslin Bay (Christophel and Blackburn, 1978; Blackburn, 1981) and Golden Grove (Christophel and Greenwood, 1987), South 


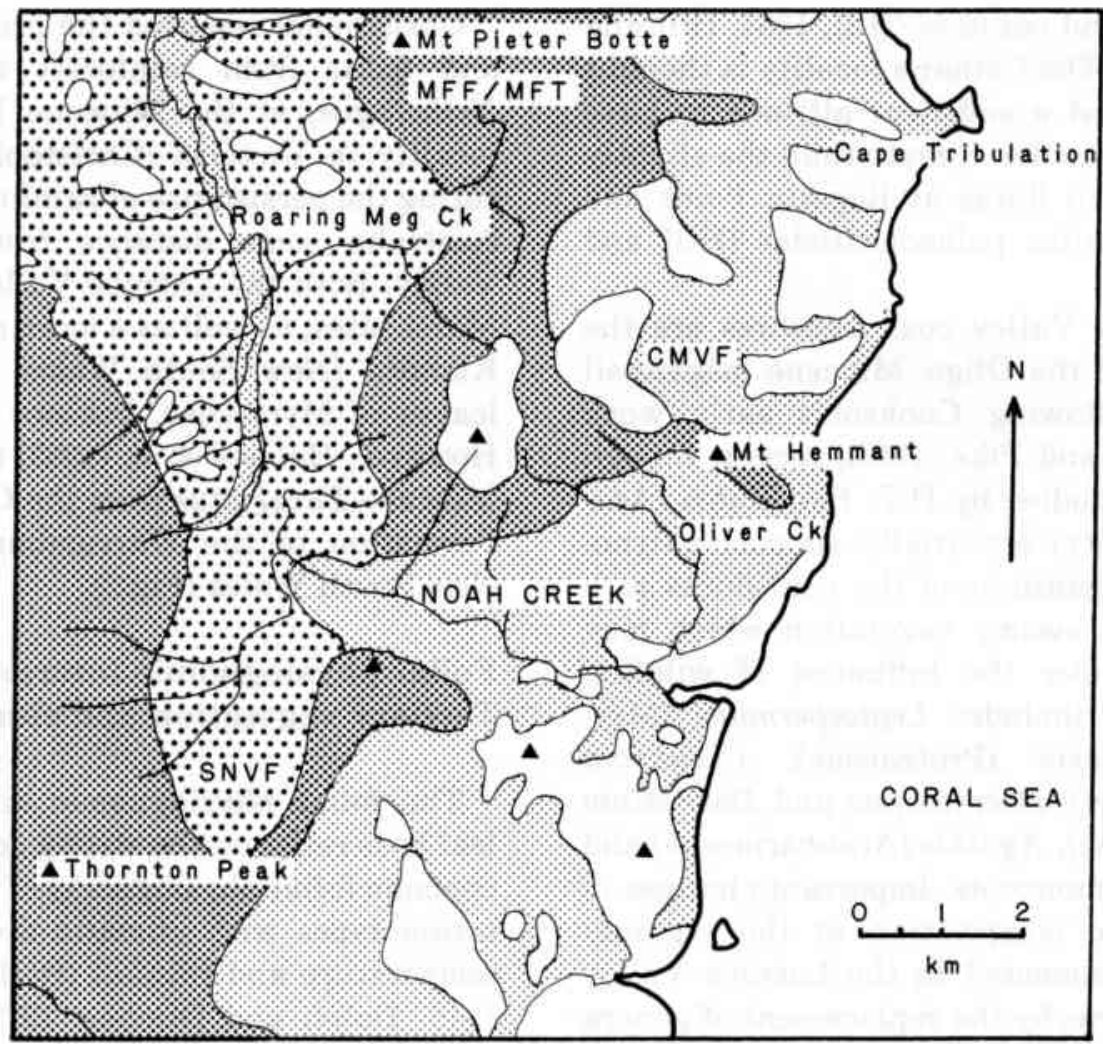

Fig.3. Simplified vegetation map of the Noah Creek region of Northeast Queensland. See Fig.2 for location. Prominent peaks indicated by solid triangles. See text for explanation. Modified from a map by Tracey and Webb, 1975.

Australia, also indicate the presence of rainforests with a tropical or subtropical character.

Christophel and Greenwood drew attention to the common presence of key taxa in the mainland megafossil floras - Brachychiton (Sterculiaceae), Podocarpus and Decussocarpus (Podocarpaceae), Gymnostoma (Casuarinaceae), Banksieaephyllum/Musgraveinanthus (Proteaceae), etc. - and suggested that some taxa may have been important constituents of Australian Tertiary vegetation (Greenwood, 1987b; Christophel and Greenwood, 1987, 1988). Most of these taxa now have very restricted distributions within Australia (Christophel, 1984; Christophel and Greenwood, 1988). However, some of these taxa are absent from the modern Australian flora e.g. Decussocarpus and Prumnopitys (Podocarpaceae), but are now present in adjacent landmasses (New Guinea and New Caledonia; Greenwood, 1987b).
One point of discrepancy between the megafossil and microfossil analyses is the apparent lack of foliar or carpological remains of Nothofagus from Eocene continental Australian deposits, which of course questions the existence of the "pan-Australian" Nothofagusrich forest mentioned earlier. Indeed, the megafossil data suggests that in the Eocene on what is now mainland Australia, a regionally diverse rainforest flora was present in which Nothofagus was rare or absent; rainforest similar in richness and complexity to that found in some parts of northern Queensland today (Christophel and Greenwood, 1987, 1988).

In Tasmania, however, there is a broader correspondence between the palynofloras and the megafossil floras, with leaves representing Nothofagus described from the Eocene-Oligocene Cethana locality in northern Tasmania, together with a diverse assemblage of other 
angiosperms and conifers (Hill, 1984; Hill and Gibson, 1986). The Cethana locality is thought to have been at a sufficient altitude to have experienced a cooler climate than the slightly older megafossil floras at Regatta Point and Hasties at similar palaeolatitudes (Hill and Gibson, 1986).

The Latrobe Valley coal measures are the best known of the Oligo-Miocene megafossil localities. Following Cookson's early work (e.g. Cookson and Pike, 1953), recent, though unpublished studies by D.T. Blackburn (Adelaide University) essentially support palynological interpretations of the coal floras as a sclerophyllous swamp vegetation which may have been under the influence of wildfire. Typical taxa include: Leptospermum (Myrtaceae), Banksia (Proteaceae), Casuarina (Casuarinaceae), Dacrycarpus and Dacrydium (Podocarpaceae), Agathis (Araucariaceae) and several reedy monocots. Important changes in the taxonomic composition of the regional floras are documented in the Latrobe Valley megafossil floras by the replacement of genera typical of the Eocene, such as Decussocarpus, Musgraveinanthus and Gymnostoma, by members of the related genera, Dacrycarpus, Banksia and Casuarina. The taxonomic character of these coal floras is similar to that of the modern sclerophyllous swamp forests or "kerangas" of Borneo where genera often considered restricted to rainforest (e.g. Agathis and Dacrydium) occur with more typically sclerophytic genera, such as Leptospermum, in a stunted "heath forest" on deep infertile sands (Brunig, 1983).

Studies by Hill and others have shown that the modern cool temperate rainforest elements had started to develop in Tasmania by the Late Oligocene, including the small-leaved southern species of Nothofagus (Hill, 1983; Hill and Macphail, 1983; Hill and Gibson, 1986). In addition, Hill and Gibson detected sub-alpine vegetation at high elevations in Tasmania, at Monpeelyata, where they recorded the winter deciduous Tasmanian endemic, Nothofagus gunnii, now characteristic of Tasmanian subalpine vegetation (Hill and Gibson, 1986).
Christophel reported the presence of leaves and fruits from rainforest taxa, including Nothofagus, at the Miocene Bacchus Marsh locality in Victoria (Christophel, 1985), indicating the persistence of rainforest in southern Australia some distance from the Latrobe Valley. Both the Latrobe Valley and Bacchus Marsh sites, as well as a more northerly site at Kiandra (New South Wales, Fig.2), contain leaves of Myrtaceae, but not Eucalyptus s.l.. However, Holmes et al. (1983) reported Middle Miocene Eucalyptus from the Chalk Mountain Formation of the Warrumbungle Ranges in New South Wales (Fig.2).

\section{Foliar physiognomic interpretations of Tertiary vegetation and climate}

The foliar physiognomic analysis of fossil leaf beds relies on the strong correlation of the common foliar physiognomy of particular vegetation types with climatic factors, primarily temperature and rainfall (Bailey and Sinnott, 1916; Dolph and Dilcher, 1979; Wolfe, 1980). These correlations have been used to form physiognomic classifications of modern forests, e.g. Webb's classification of Australian rainforests (Webb, 1959; Tracey, 1982) and Wolfe's classification of the mesic forests of east Asia (Wolfe, 1980). Tertiary leaf-beds have often been interpreted by matching the proportions of individuals or species represented in, leafsize classes (e.g. sensu Webb, 1959), or leafmargin type, for the modern forest canopy to that observed in the fossil leaf-bed (e.g. MacGinitie, 1969; Christophel, 1981; Wolfe, 1987).

The direct comparison of the foliar physiognomic character of Tertiary leaf-beds to modern vegetation classifications can be criticised for ignoring the taphonomy of leaf-beds. The modern classifications are based on the foliar physiognomic character of the canopy alone (e.g. Webb, 1959; Wolfe, 1980). Leaf-beds, however, contain leaves from all of the forest synusiae (Dolph, 1984; Ferguson, 1985) and often represent leaf populations of quite different physiognomic character to the canopy 
(Dolph, 1984; Roth, 1984). The suggestion is that interpretations based on canopy correlations will inaccurately predict the source forest or climate of the fossil leaf-bed.

In order to answer these criticisms, Greenwood determined the "foliar physiognomic signatures" of extant leaf-beds derived from Webb's four main rainforest types (Greenwood, 1987a; Christophel and Greenwood, 1988). Further work not reported elsewhere will be discussed here, however, a more complete discussion is currently in preparation. Early Tertiary floras from Australia are generally interpreted as representing rainforest (Christophel and Blackburn, 1978; Christophel, 1981; Hill and MacPhail, 1983; Christophel et al., 1987). It is therefore appropriate that the foliar physiognomy of modern Australian rainforest be studied to interpret the Tertiary floras.

Four main rainforest types can be recognised from Webb's classification, each of which broadly correspond to the traditional classification of tropical - Complex Mesophyll Vine Forest (CMVF), subtropical Complex Notophyll Vine Forest (CNVF), montane tropical to warm temperate - Simple Notophyll Vine Forest (SNVF), and cool temperate rainforest - Microphyll Mossy or Fern Forest (MMF/MFF) (Webb, 1959, 1968; Tracey, 1982). The modern distribution of each of these forest types (Fig.4) is primarily determined by climate, although edaphic factors are important at a local scale (Webb, 1968; Tracey, 1982). The modern altitudinal range of these forest types in the Tropical (Mesothermal to Megathermal, sensu Wolfe, 1980), Subtropical (Mesothermal in part), and Temperate (Mesothermal to Microthermal) zones is depicted to the right of Fig.4. It can be seen that there is a progressive elimination of the warmer forest types with increasing latitude (and altitude), with only SNVF and MMF present south of about $35^{\circ} \mathrm{S}$.

Leaf-litter was collected from the forest floor and in stream beds for each of the four rainforest types at locations in Northeast Queensland (Fig.6) and New South Wales. Each of these leaf-beds was shown to retain a

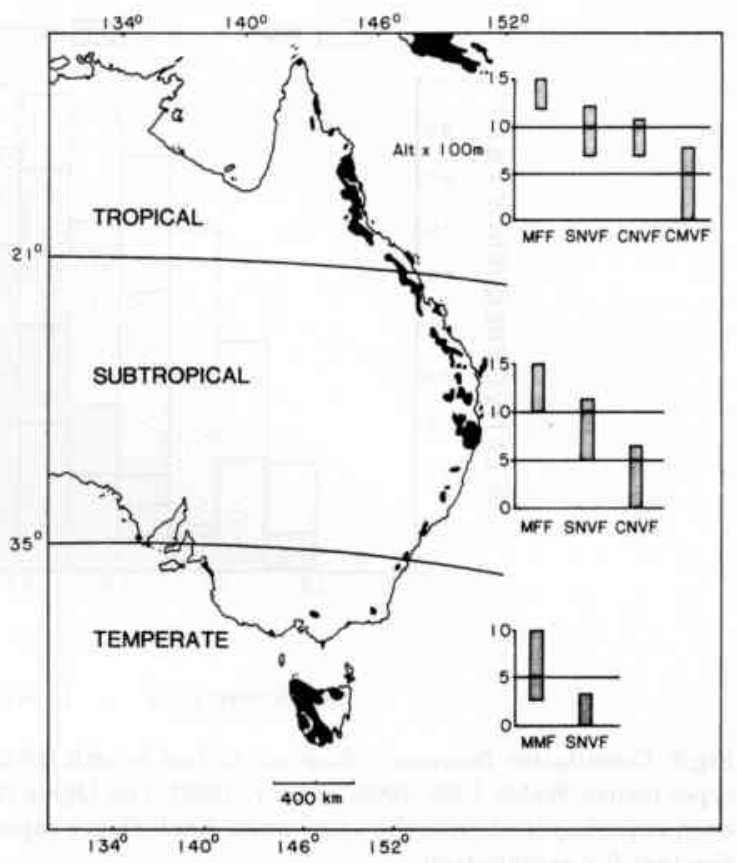

Fig.4. The modern distribution of rainforest in Australia. The altitudinal range of the four main rainforest types (sensu Webb, 1959, 1968) for the three climatic zones is indicated on the graphs to the right of the figure. Based on data from Tracey (1982) and Webb and Tracey (1984).

unique "foliar physiognomic signature" represented by the frequency distribution of leaf length and width (Greenwood, 1987a; Christophel and Greenwood, 1988). This data is presented in Fig.5 as a cumulative frequency diagram, where the Ogive (stepped function of cumulative frequency) of leaf length $(10 \mathrm{~mm}$ classes) of each of the four forest types has been superimposed on the same axis. The height of each bar indicates the proportion of leaves below the size indicated for each of the four forest types (note that the superimposition of the four ogives obscures the lower part of each bar for MMF, SNVF, and CNVF). The intervals covered by Webb's leaf-size categories (Webb, 1959) are also indicated.

Figure 5 shows that there is a stepwise decrease in leaf length in the leaf-litter from the warmest rainforest type, CMVF (Mesothermal to Megathermal), to the coolest rainforest type, MMF (Microthermal). A similar pattern is found for leaf width, although the Ogives of 


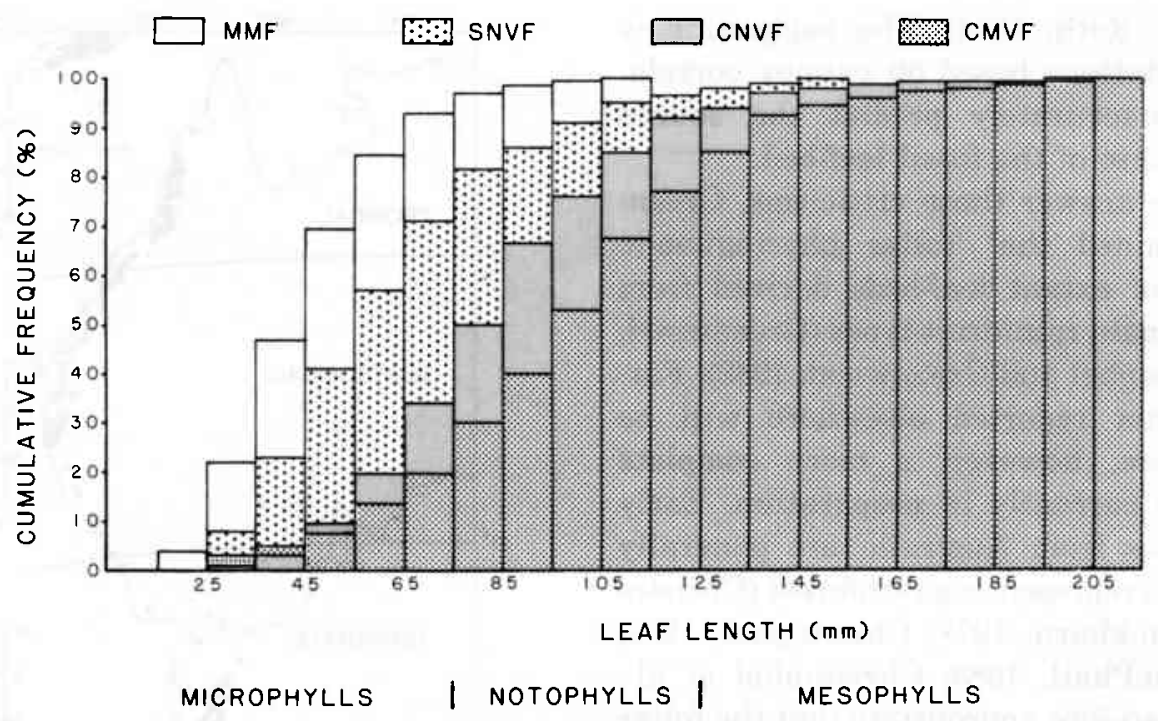

Fig.5. Cumulative frequency diagram of leaf length (10 mm classes) for leaf-litter samples from four Australian rainforest types (sensu Webb, 1959, 1968; Tracey, 1982). The Ogive (the stepped frequency function) of each of the rainforest types has been superimposed onto the same axes. Each Ogive represents the "foliar physiognomic signature" of the rainforest type. See text for explanation.

CNVF and CMVF are poorly separated (Greenwood, 1987a). These leaf length and width cumulative frequency diagrams form the "foliar physiognomic signatures" of leaf-beds derived from each forest type, however, the effects of stream transport on these signatures were also examined.

Several studies have suggested that leaf-beds deposited into water bodies may be biased towards smaller leaf sizes than present in the source vegetation due to the combined effects of the differential transport capacities of large and small leaves, and their differential survival during transport, due to mechanical and biological decay (Spicer, 1981; Ferguson, 1985). This was examined in a rainforest situation by comparing the foliar physiognomic signatures of leaf-beds formed from transported (allochthonous) and untransported (autochthonous) leaves sampled from a stream-bed in Simple Notophyll Vine Forest (SNVF) on the Mt. Windsor Tableland in Northeast Queensland (Fig.6) (Greenwood, 1987a).

The autochthonous leaf-bed represents leaves which accumulated in a series of pools in the stream course where the forest com- pletely over-arched the stream. Several hundred meters downstream, a rapid empties into a large pool where the forest edge is a few meters from the stream edge. A leaf accumulation in this pool was sampled to represent an allochthonous leaf-bed. The leaf length Ogives of the two leaf-beds are superimposed on the same axes of a cumulative frequency diagram in Fig.7. It can be clearly seen that the allochthonous sample contains significantly smaller leaves than the autochthonous sample, as illustrated by the mean leaf length of the two samples: 68.3 and $80.9 \mathrm{~mm}$.

When the leaf width frequency diagram of the two samples is examined (Fig.8), the same result is apparent with a significantly smaller leaf width for the allochthonous sample. However, a forest floor sample from another SNVF site, Mt. Lewis (see Fig.6), was added for comparison. The autochthonous (stream-bed) sample contained much larger leaves than the forest floor, indicating a larger-leaved streamside flora (as predicted by MacGinitie, 1969). However, the selection of smaller leaves by stream transport has in part removed this bias. Fossil leaf-beds are therefore likely to be 


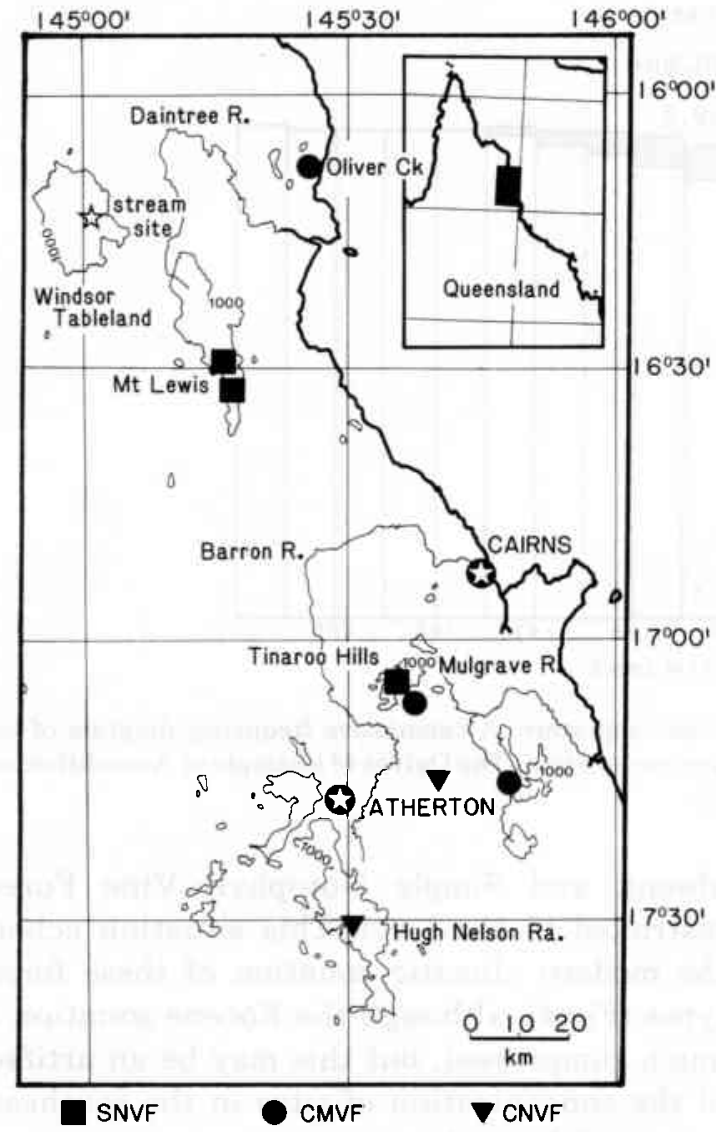

Fig.6. Location map of the leaf-bed sample points used for the analysis of the foliar physiognomic signatures of leafbeds sourced from modern Australian rainforests. The stream site is indicated by an open star.

biased towards smaller leaf sizes compared to leaf-litter from the same forest type. The best match for a fossil leaf-bed will therefore be with the forest type with the same foliar physiognomic signature (the same Ogive of leaf length and width), or a bias towards smaller leaves (i.e. the length or width Ogive slightly shifted to the left of the cumulative frequency diagram).

The few Tertiary megafossil floras analysed using the foliar physiognomic signatures allow an overview of Australian Tertiary vegetation and climate. The leaf length cumulative frequency diagram (Fig.9) of three Early Tertiary floras from southern Australia - Cethana in Tasmania, Anglesea in Victoria, and Maslin
Bay in South Australia (see Fig.2), illustrates the presence of signatures in Tertiary leaf-beds similar to those detected in modern leaf-litter (Fig.5). From this data the presence of three of Webb's rainforest types has been detected reflecting a range of climates from humid subtropical (Mesothermal) to cool temperature (Microthermal). The Cethana data is, however, preliminary (R. Carpenter, University of Tasmania, pers. commun., 1987), as is the Maslin Bay data.

The foliar physiognomic signature data support an interpretation of the Anglesea flora as marginal Mesothermal Simple Notophyll Vine Forest. Similar data for Nerriga in New South Wales, and Golden Grove in South Australia (see Fig.2 for locations), suggest that both are Mesothermal Complex Notophyll Vine Forest (Christophel and Greenwood, 1987, 1988). Maslin Bay is interpreted provisionally as Complex Notophyll Vine Forest also. However, there are some aspects of the signature of the Maslin Bay flora which suggests Complex Mesophyll Vine Forest as a better match. Wolfe (1980, 1987) interpreted Complex Mesophyll Vine Forest as Mesothermal vegetation, however, a recent analysis of the thermal limits of modern Australian rainforest found that CMVF overlaps into the Megathermal regime (Greenwood, 1987a). Thus, it is possible that the Maslin Bay megafossil flora represented Megathermal vegetation.

Figure 10 shows the analysed Eocene deposits mapped on a reconstruction of Australia in the Eocene. All of the sites are Middle Eocene. From the inferred forest types of these Early Tertiary megafossil floras there is a suggestion of climatic zonation. The altitude and forest type of each of the floras is shown to the right of Fig.10. The more northerly sites (Golden Grove, Maslin Bay, and Nerriga) indicate Mesothermal Complex Notophyll Vine Forest from sea level to about 500 meters, with perhaps also Megathermal-Mesothermal Complex Mesophyll Vine Forest at sea level if Maslin Bay is interpreted as CMVF. The regional pollen rain suggests that cooler forest types must have occurred at higher altitudes 


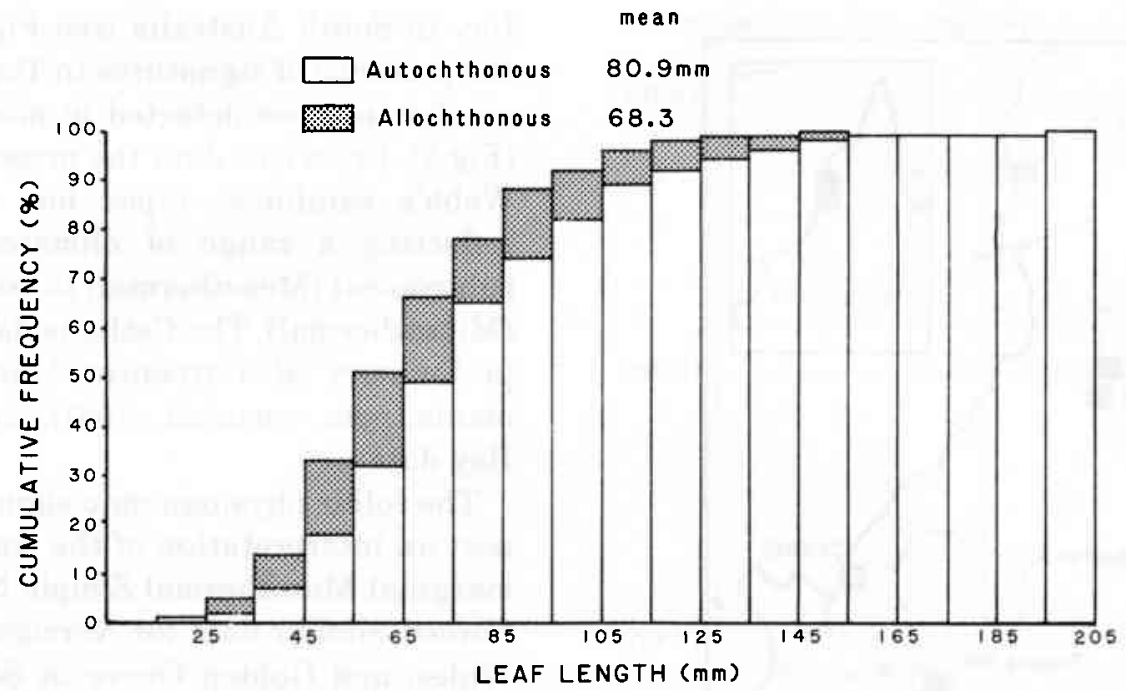

Fig.7. The effect of stream transport on the leaf length physiognomic signature. A cumulative frequency diagram of leaf length (10 mm classes) for leaves sampled in a streambed. See text for explanation. The Ogives of a sample of Autochthonous leaves has been superimposed over that of a Allochthonous sample.

(i.e. abundant Nothofagus pollen). The more southerly sites (Anglesea and Dean's Marsh) exhibit a shift in the altitudinal ranges of the forest types, with Complex Mesophyll Vine Forest and Complex Notophyll Vine Forest

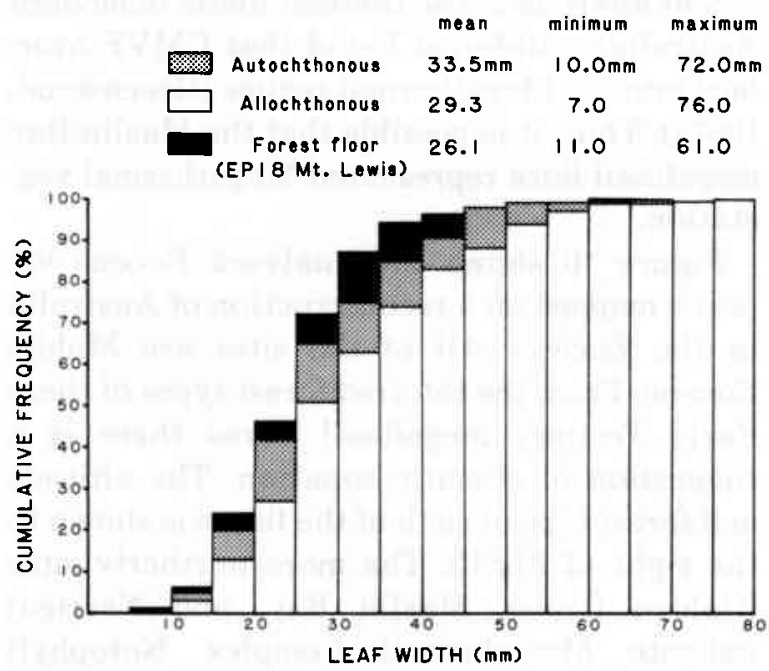

Fig.8. The effect of stream transport on the leaf width physiognomic signature. A cumulative frequency diagram of leaf width ( $5 \mathrm{~mm}$ classes) for leaves sampled in a stream bed. See Fig. 7 and text for explanation. The ogives of a forest floor site (Mt. Lewis) and the Autochthonous sample have been superimposed on the Ogive of the Allochthonous sample. absent, and Simple Notophyll Vine Forest restricted to sea level. This situation echoes the modern climatic zonation of these forest types (Fig.4), although the Eocene zonation is much compressed, but this may be an artifact of the concentration of sites in the southeast corner of Australia.

However, the close proximity of floras of quite different foliar physiognomic character offers an alternative explanation. The discussion on floristics mentioned the common presence of key taxa in three of these floras (Christophel and Greenwood, 1987, 1988). This may be interpreted as a regionally uniform rainforest flora. Reference to a modern rainforest situation in Australia serves to explain a possible alternative model for the Eocene vegetation patterns. Within a small area of Northeast Queensland, the Atherton Tableland (Fig.11), all of the major rainforest types coexist. These forests share many species (Tracey, 1982), and the physiognomic differences are produced by combinations of edaphic and climatic differences associated with altitude and soil type (Webb, 1968; Tracey, 1982; Greenwood, 1987a). Thus several models are plausible for the Eocene, including:

(1) local mosaics of rainforest types produced 


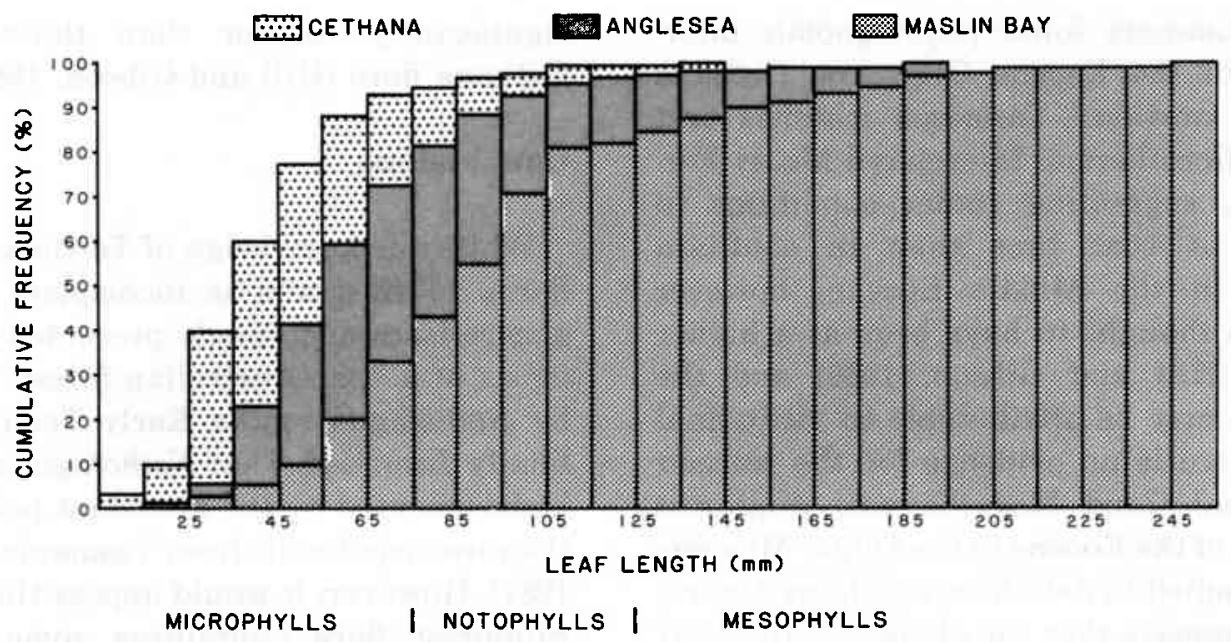

Fig.9. The leaf length foliar physiognomic signatures of three Early Tertiary megafossil floras. A cumulative frequency diagram of leaf length (10 mm classes) with the Ogives of leaf length for each of the localities superimposed onto the same axes. See text for explanation.

by climatic-edaphic interactions with some species shared, or (2) regional climatically determined vegetational belts.

Given the wide geographical separation of the fossil floras and the consistency of the altitudinal differences, it seems more likely that some climatic zonation was in place in southern Australia in the Eocene.
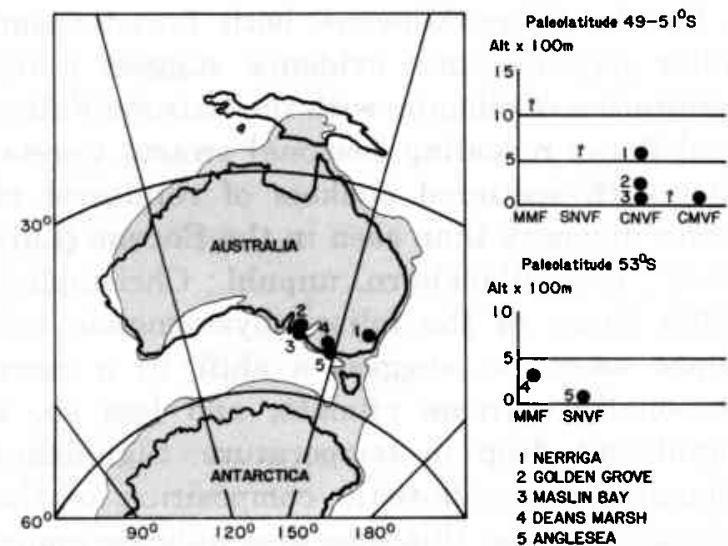

Fig.10. Reconstruction of Australia in the Eocene showing location and palaeolatitude of the Eocene megafossil localities used in the foliar physiognomic analysis. The estimated altitudes and inferred forest type of each Eocene flora is shown graphically to the right of the map. Eocene base map adapted from Smith et al., 1981. Eocene coastline based on Veevers, 1984.

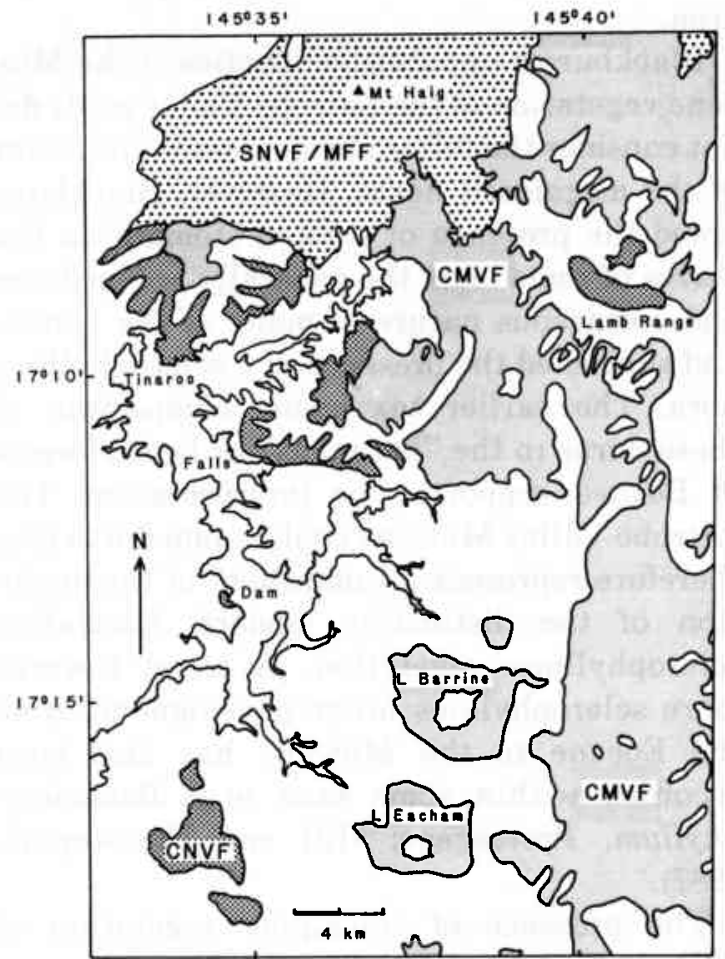

Rainforest Distribution on the

Atherton Tableland (NE Queensland)

Fig.11. Simplified vegetation map of the northeastern quarter of the Atherton Tableland (see Fig.6). Blank areas are mostly cleared, and would have carried rainforest prior to European settlement. Adapted from Tracey and Webb, 1975. 
The preliminary foliar physiognomic interpretation of the Eocene-Oligocene Cethana flora from northern Tasmania matches best with the Microthermal Microphyll Mossy Forest (Fig.9), suggesting cooler conditions in Tasmania at that time than in southern Australia in the Middle Eocene, however Cethana is thought to have been at a higher elevation (Hill and Gibson, 1986) and the differences may be attributable to altitudinal effects. There is no evidence for the warmer Mesothermal (?and Megathermal) rainforest vegetation of the Eocene in the Oligo-Miocene deposits studied to date from southern Australia. This suggests that the climate of this part of Australia by the Oligo-Miocene was not very different to that of today as Simple Notophyll Vine Forest and Microphyll Mossy Forest are the main rainforest types of this area.

Blackburn's unpublished studies of the Miocene vegetation of the Latrobe Valley coals did not consider the foliar physiognomic character of the megafossil floras. However, Blackburn noted the presence of sunken stomata on the leaves of some taxa, the generally reduced size and coriaceous nature of many of the leaves, and suggested the presence of a sclerophyllous flora. The earlier taxonomic comparison of these floras to the "kerangas" or heath-forests of Borneo supports this interpretation. The Latrobe Valley Miocene coal swamp floras may therefore represent a "snapshot" of the evolution of the distinctive modern Australian sclerophyllous vegetation. A trend towards more sclerophyllous foliar physiognomy from the Eocene to the Miocene has also been recorded within some taxa (e.g. Banksieaephyllum, Proteaceae; Hill and Christophel, 1987).

The presence of sub-alpine vegetation at altitude is also indicated for the Oligo-Miocene as Hill and Gibson interpreted the Monpeelyata megafossil flora (Tasmania) as being from subalpine vegetation as the foliar physiognomic characteristics of the flora are similar to leaf litter collected from a modern sub-alpine lake, and the leaves from Monpeelyata are significantly smaller than those from the Cethana flora (Hill and Gibson, 1986).

\section{Conclusions}

While our knowledge of Tertiary megafossil floras in Australia is incomplete, the broad generalisations formerly presented by palynologists of a "pan-Australian forest" dominated by Nothofagus in the Early Tertiary can be finally dismissed. That Nothofagus was present is documented by the abundant pollen and by the rare megafossils from Tasmania (Hill, 1984, 1987). However, it would appear that a diverse rainforest flora containing some taxa now restricted to Northeast Queensland rainforests or adjacent landmasses was present in southern Australia in the Eocene (e.g. Christophel and Basinger, 1982; Christophel and Greenwood, 1987, 1988; Greenwood, 1987b; Hill and Bigwood, 1987). The foliar physiognomic character of these Eocene rainforests suggests that they represented Mesothermal (i.e. SNVF and CNVF) and perhaps Megathermal vegetation (CMVF) at high southern latitudes (Fig.10), but that a rapid transition to cooler Microthermal rainforests (MMF) occurred with increasing altitude, and at higher latitudes.

By the Oligo-Miocene both floristic and foliar physiognomic evidence suggest a deterioration of climate, with the Latrobe Valley coal floras revealing seasonal swamp vegetation with scattered pockets of rainforest of lower diversity than seen in the Eocene (Luly et al., 1982; Blackburn, unpubl.; Christophel, 1988). Some of the foliar physiognomic evidence seems to suggest a shift to a more seasonally extreme climate, and less so, a significant drop in temperature. Significant changes in the floristic composition of the microfloras over this time also indicate major changes associated with climatic change (e.g. Kemp, 1981; Truswell et al., 1984). By the Late Miocene the vegetation was taking on an increasingly more temperate flavour with the modern-type small-leaved species of Nothofagus from Tasmania and Victoria supplanting 
the larger leaved forms (Hill, 1983). There is also evidence for the rising dominance of the now typical Eucalyptus dominated vegetation at this time (e.g. Holmes et al., 1983) and the presence of sub-alpine vegetation at higher altitude in Tasmania (Hill and Gibson, 1986).

Hill and Read (1987) considered that much of the endemism of the modern Tasmanian flora reflects the local extinction of Eocene taxa (e.g. Nothofagus brassii group), and both the persistence of some taxa in Tasmania and not the mainland (e.g. Phyllocladus), and the evolution of new taxa, initiated by Tertiary climatic changes. Their hypothesis can be extended to the whole of southern Australia, as it would seem that the mainland Early Tertiary floras demonstrate similar climatic sifting, with particular taxa becoming locally extinct by the Late Miocene, surviving today in favourable situations in either N.E. Queensland or adjacent landmasses (e.g. Orites, Musgraveinae, Prumnopitys, Bowenia, and Decussocarpus; Christophel and Greenwood, 1988).

The character of the vegetation of Australia in the Pliocene and Pleistocene is considered to have been essentially as we see it today, although some Early Tertiary taxa persisted until the Pleistocene in some areas (e.g. Nothofagus in Northeast Queensland, Kershaw and Sluiter, 1982). The boundaries and spatial extent of the major vegetation types, however, have fluctuated with the ebb and flow of glaciation (Kershaw, 1981). Australia's rainforests, based on the emerging picture of Early Tertiary vegetation in particular, increasingly appear to represent important repositories of ancient plant and vegetation types. However, the extinctions and evolutionary sifting of the rainforest and non-rainforest vegetation over the Tertiary have left their mark, producing patterns of endemism that reflect both ancient inheritance, and recent evolution (Hill and Read, 1987; Christophel and Greenwood, 1988). Australia's rainforests, particularly the tropical rainforests, may therefore be viewed as an essentially relict flora surrounded by a sea of evolutionary novelty, the Eucalyptus dominated forests and woodlands.

\section{Acknowledgements}

The authors would like to thank the following people for their help and advice: B.P.M. Hyland, B. Gray, G. Unwin, G. Stocker, and J.G. Tracey of the C.S.I.R.O. Tropical Forest Research Centre, Atherton; the National Parks and Wildlife Services of Queensland and New South Wales for permission to work in National Parks; The Queensland Forestry Commission, for permission to work in their Reserves; and Sue Shaw for preparing the final versions of the figures. This research was funded by the Australian Research Grants Scheme and DRG's research in Northeast Queensland by the University of Adelaide Holtz Fund.

\section{References}

Bailey, I.W. and Sinnott, E.W., 1916. The climatic distribution of certain kinds of angiosperm leaves. Am. J. Bot., 3: 24-39.

Barlow, B.A., 1981. The Australian Flora: Its Origin and Evolution. In: Flora of Australia. Aust. Gov. Print. Serv., Canberra, Vol.1, pp.25-75.

Blackburn, D.T., 1981. Tertiary megafossil flora of Maslin Bay, South Australia: numerical taxonomic study of selected leaves. Alcheringa, 5: 9-28.

Brunig, E.F., 1983. Vegetation structure and growth. In: F.B. Golley (Editor), Tropical Rainforest Ecosystems: Structure and Function (Ecosystems of the World, 14A.) Elsevier, Amsterdam, pp.49-76.

Christophel, D.C., 1981. Tertiary megafossil floras as indicators of floristic associations and palaeoclimate. In: A. Keast (Editor), Ecological Biogeography of Australia. Junk, The Hague, pp.379-390.

Christophel, D.C., 1984. Early Tertiary Proteaceae: The first floral evidence for the Musgraveinae. Aust. J. Bot., 32: $177-186$.

Christophel, D.C., 1985. First record of well preserved megafossils of Nothofagus from mainland Australia. Proc. R. Soc. Victoria, 97: 175-178.

Christophel, D.C., 1989. Evolution of the Australian flora through the Tertiary. Plant Syst. Evol., (in press).

Christophel, D.C. and Basinger, J.F., 1982. Earliest floral evidence for the Ebenaceae in Australia. Nature, 296(5856): 439-441.

Christophel, D.C. and Blackburn, D.T., 1978. The Tertiary megafossil flora of Maslin Bay, South Australia - a preliminary report. Alcheringa, 2: 311-319. 
Christophel, D.C. and Greenwood, D.R., 1987. A new Eocene megafossil flora from Golden Grove, South Australia. Trans. R. Soc. South Aust., 111(3): 155-162.

Christophel, D.C. and Greenwood, D.R., 1988. A comparison of Australian tropical rainforest and Tertiary leafbeds. In: The Ecology of Australia's Wet Tropics. Proc. Ecol. Soc. Aust., 15: 139-148.

Christophel, D.C., Harris, W.K. and Syber, A.K., 1987. The Eocene flora of the Anglesea locality, Victoria. Alcheringa, 11: 303-323.

Cookson, I.C. and Pike, K.M., 1953. The fossil occurrence of Phyllocladus and two other podocarpaceous types in Australia. Aust. J. Bot., 2: 60-68.

Dolph, G.E., 1984. Leaf form of the woody plants of Indiana as related to environment. In: N.S. Margaris, M. Arianoustou-Farragitaki and W.C. Oechel (Editors), Being Alive on Land (Tasks for Vegetation Science 13.) Junk, The Hague, pp.51-61.

Dolph, G.E. and Dilcher, D.L., 1979. Foliar physiognomic analysis as an aid in determining palaeoclimate. Palaeontographica Abt. B, 170: 151-172.

Ferguson, D.K., 1985. The origin of leaf assemblages new light on an old problem. Rev. Palaeobot. Palynol., 46: 117-188.

Foster, C., 1983. Illustrations of Early Tertiary (Eocene) plant microfossils from the Yaamba Basin, Queensland. Geol. Surv. Queensl. Publ. 381, 33 pp.

Greenwood, D.R., 1987a. The foliar physiognomic analysis and taphonomy of leaf-beds derived from modern australian rainforest. Ph.D. Thesis, University of Adelaide, South Australia (unpublished) $143 \mathrm{pp}$.

Greenwood, D.R., 1987b. Early Tertiary Podocarpaceae: megafossils from the Eocene Anglesea locality, Victoria, Australia. Aust. J. Bot., 35(2): 111-133.

Hill, R.S., 1982. The Eocene megafossil flora of Nerriga, New South Wales, Australia. Palaeontographica Abt. B, 181: 44-77.

Hill, R.S., 1983. Evolution of Nothofagus cunninghamii and its relationship to $N$. moorei inferred from Tasmanian macrofossils. Aust. J. Bot., 31: 453-466.

Hill, R.S., 1984. Tertiary Nothofagus macrofossils from Cethana, Tasmania. Alcheringa, 8: 81-86.

Hill, R.S., 1986. Lauraceous leaves from the Eocene of Nerriga, New South Wales. Alcheringa, 10: 327-351.

Hill, R.S., 1987. Discovery of Nothofagus fruits corresponding to an important Tertiary pollen type. Nature, 327(6117): 56-58.

Hill, R.S. and Bigwood, A.J., 1987. Tertiary gymnosperms from Tasmania: Araucariaceae. Alcheringa, 10: 325-336.

Hill, R.S. and Christophel, D.C., 1987. Tertiary leaves of the tribe Banksieae (Proteaceae) from south-eastern Australia. Bot. J. Linn. Soc., 97: 205-227.

Hill, R.S. and Gibson, N., 1986. Distribution of potential macrofossils in Lake Dobson, south central Tasmania, Australia. J. Ecol., 74: 373-384.

Hill, R.S. and Macphail, M.K., 1983. Reconstruction of the Oligocene vegetation at Pioneer, northeast Tasmania. Alcheringa, 7: 281-299.

Hill, R.S. and Read, J., 1987. Endemism in Tasmanian cool temperate rainforest: alternative hypotheses. Bot. J. Linn. Soc., 95: 113-124.

Holmes, W.B.K., Holmes, F.M. and Martin, H.A., 1983. Fossil Eucalyptus remains from the Middle Miocene Chalk Mountains Formation, Warrumbungle Mountains, New South Wales. Proc. Linn. Soc. N.S.W., 106(4): 299-310.

Kemp, E.M., 1978. Tertiary climate evolution and vegetation history in the S.E. Indian Ocean region. Palaeogeogr., Palaeoclimatol., Palaeoecol., 24: 169-208.

Kemp, E.M., 1981. Tertiary palaeogeography and the evolution of Australian climate. In: A. Keast (Editor), Ecological Biogeography of Australia. Junk, The Hague, pp.31-50.

Kershaw, A.P., 1976. A Late Pleistocene and Holocene pollen diagram from Lynch's Crater, northeastern Queensland, Australia. New Phytol., 77: 469-498.

Kershaw, A.P., 1981. Quaternary vegetation and environments. In: A. Keast (Editor), Ecological Biogeography of Australia. Junk, The Hague, pp.81-102.

Kershaw, A.P. and Sluiter, I.R., 1982. Late Cenozoic pollen spectra from the Atherton Tableland, northeastern Queensland, Australia. Aust. J. Bot., 30: 279-295.

Luly, J., Sluiter, I.R. and Kershaw, A.P., 1980. Pollen studies of Tertiary brown coals. Preliminary analysis of lithotypes within the Latrobe Valley, Victoria. Monash University Publ. Geogr., 23, 78 pp.

MacGinitie, H.D., 1969. The Eocene green River flora of northwestern Colorado and northeastern Utah. Univ. Calif. Publ. Geol. Sci., 83: 1-140.

Martin, H.A., 1981. The Tertiary flora. In: A. Keast (Editor), Ecological Biogeography of Australia. Junk, The Hague, pp.391-406.

Roth, I., 1984. Stratification in tropical forests as seen in leaf structure. Tasks for Vegetation Science, 6, Junk, The Hague, pp.186.

Sluiter, I.R. and Keshaw, A.P., 1982. The nature of Late Tertiary vegetation in Australia. Alcheringa, 6: 211-222.

Smith, A.G., Hurley, A.M. and Briden, J.C., 1981. Phanerozoic palaeocontinental world maps. Cambridge Earth Sci. Ser., Cambridge Univ. Press, 102 pp.

Spicer, R.A., 1981. The sorting and deposition of allochthonous plant material in a modern environment at Silwood Lake, Silwood Park, Berkshire, England. U.S. Geol. Surv. Prof. Pap., 1143: 77 pp.

Tracey, J.G., 1982. The Vegetation of the Humid Tropics of North Queensland. CSIRO, Melbourne, 124 pp.

Tracey, J.G. and Webb, L.J., 1975. Vegetation of the Humid Tropical Region of North Queensland. Rainforest Ecol. Unit, Div. Plant Ind., CSIRO Long Pocket Lab., Indooroopilly, Qld. (15 maps at 1:100,000 scale+ key).

Truswell, E.M. and Harris, W.K., 1982. The Cainozoic palaeobotanical record in arid Australia: fossil evidence for the origin of an arid-adapted flora. In: W.R. Barker and P.J.M. Greenslade (Editors), Evolution of the Flora and Fauna of Arid Australia. Peacock Publ., South Australia, pp.67-76.

Truswell, E.M. and Marchant, N.G., 1986. Early Tertiary 
pollen of probable Droseracean affinity from central Australia. Spec. Pap. Palaeontol., Bur. Min. Res. Canberra, 35: 163-178.

Truswell, E.M., Sluiter, I.R. and Harris, W.K., 1984. Palynology of the Oligocene-Miocene sequence in the Oakvale-1 corehole, western Murray Basin, South Australia. B.M.R. J. Geol. Geophys., 9(4): 267-296.

Veevers, J.J., 1984 (Editor), Phanerozoic earth history of Australia. Oxford Geol. Sci. Ser., 2, 418 pp.

Webb, L.J., 1959. A physiognomic classification of Australian rainforests. J. Ecol., 47: 551-570.

Webb, L.J., 1968. Environmental determinants of the structural types of Australian rainforest vegetation. Ecology, 49: 296-311.

Webb, L.J. and Tracey, J.G., 1982. Rainforests: data on floristics and site characteristics. Biogeogr. Inform. Syst., Bureau of Flora and Fauna, Canberra.

Wolfe, J.A., 1980. Temperature parameters of Humid to Mesic forests of eastern Asia and relation to forests of other regions of the Northern Hemisphere and Australasia. U.S. Geol. Surv. Prof. Pap., 1106: 1-37.

Wolfe, J.A., 1987. The distribution of major vegetational types during the Tertiary. In: The Carbon Cycle and Atmospheric $\mathrm{CO}_{2}$. Natural Variations Archean to Present. Geophys. Monogr. 32, Am. Geophys. Union, Washington, D.C., pp.357-375.

Wolfe, J.A. and Upchurch, G.R., 1987. North American nonmarine climates and vegetation during the Late Cretaceous. Palaeogeogr., Palaeoclimatol., Palaeoecol., 61: 33-77. 